\title{
Morphological analysis of Rhynchospio aff. asiatica (Annelida: Spionidae) and comments on the phylogeny and reproduction of the family Spionidae*
}

\author{
Zhi WANG ${ }^{1, * *}$, Ting XU ${ }^{2,3,4}$, Jian-Wen QIU ${ }^{3,4}$, Yinglu JI ${ }^{5}$, Zishan $\mathrm{YU}^{6}$, Caihuan $\mathrm{KE}^{1}$ \\ ${ }^{1}$ State Key Laboratory of Marine Environmental Science, College of Ocean and Earth Sciences, Xiamen University, Xiamen \\ 361102, China \\ ${ }^{2}$ Department of Ocean Science and Hong Kong Branch of the Southern Marine Science and Engineering Guangdong Laboratory \\ (Guangzhou), Hong Kong University of Science and Technology, Hong Kong 999077, China \\ ${ }^{3}$ Southern Marine Science and Engineering Guangdong Laboratory (Guangzhou), Guangzhou 511458, China \\ ${ }^{4}$ Department of Biology and Hong Kong Branch of the Southern Marine Science and Engineering Guangdong Laboratory \\ (Guangzhou), Hong Kong Baptist University, Hong Kong 999077, China \\ ${ }^{5}$ North China Sea Marine Forecasting Center of State Oceanic Administration, Qingdao 266061, China \\ ${ }^{6}$ College of Marine Life Sciences, Ocean University of China, Qingdao 266003, China
}

Received Mar. 1, 2021; accepted in principle Apr. 9, 2021; accepted for publication Jun. 21, 2021

(C) Chinese Society for Oceanology and Limnology, Science Press and Springer-Verlag GmbH Germany, part of Springer Nature 2022

\begin{abstract}
The genus Rhynchospio has fronto-lateral horns on prostomium, paired branchiae from chaetiger 2 to near the posterior end, capillary notochaetae only, and more than two pairs of pygidial cirri. Rhynchospio species are common in coastal soft bottom communities; nevertheless, many recorded Rhynchospio specimens around the world are currently undescribed. Here we described a Rhynchospio species based on specimens collected from Qingdao, China. Comparison with the reported DNA sequences of four gene markers (16S rRNA, 18S rRNA, 28S rRNA, and Histone H3) and brief morphological description of specimens collected from Jinhae Bay, South Korea, previously reported as Rhynchospio aff. asiatica, indicated that they are conspecific. Morphologically, specimens of $R$. aff. asiatica from Qingdao are characterized by having neuropodial hooded hooks from chaetigers 14-17 (vs. 10-23 in R. asiatica) to near pygidial chaetigers, sperm from chaetiger 11 to 14 (vs. from chaetiger 11 to 21-22 in R. asiatica), oocytes from chaetigers 16-17 to 26-39 (vs. from 22-24 in $R$. asiatica), and 4-6 (vs. up to 6 in $R$. asiatica) pygidial cirri. Genetically, Rhynchospio aff. asiatica is most closely related to $R$. arenincola Hartman, 1936 from California, USA with the interspecific distances of $20.02 \%$ (16S rRNA), 4.50\% (18S rRNA), 8.44\% (28S rRNA), 2.74\% (Histone H3), and 6.10\% (concatenated sequences). Water flow across the dorsum created by ciliary beating of the branchiae and nototrochs, observed on live specimens, may help transport gametes from reproductive segments in anterior and middle parts to the posterior brooding segments. Phylogenetic trees based on concatenated sequences of four gene markers of 54 spioniform species in 25 genera revealed two clades, covering the two subfamilies Spioninae and Nerininae respectively. Two families (i.e., Poecilochaetidae and Trochochaetidae) in the order Spionida were clustered within Spionidae, supporting a morphology-based proposal that these families bearing a pair of prehensile, grooved palps should be grouped within a more broadly defined family Spionidae. Mapping morphological and reproductive characteristics to the phylogenetic trees indicated that the ancestor of spionids might lack branchiae, broadcast spawn thick-envelop oocytes and ect-aquasperm, and produce planktotrophic larvae.
\end{abstract}

Keyword: Annelida; phylogeny; taxonomy; Yellow Sea

\section{INTRODUCTION}

Spionidae Grube, 1850 is a large family of annelids containing 39 valid genera and over 630 valid species (Read and Fauchald, 2021). There have been

\footnotetext{
* Supported by the China Postdoctoral Science Foundation (No. 2021M691866), the Key Special Project for Introduced Talents Team of Southern Marine Science and Engineering Guangdong Laboratory (Guangzhou) (Nos. GML2019ZD0404, GML2019ZD0409), the Hong Kong Branch of Southern Marine Science and Engineering Guangdong Laboratory (Guangzhou) (No. SMSEGL20SC02), the MEL Outstanding Postdoctoral Scholarship, and the Undergraduate Innovation and Entrepreneurship Training Programs at Xiamen University (No. 202110384077)

** Corresponding author: zhiwang00kxy@xmu.edu.cn
} 


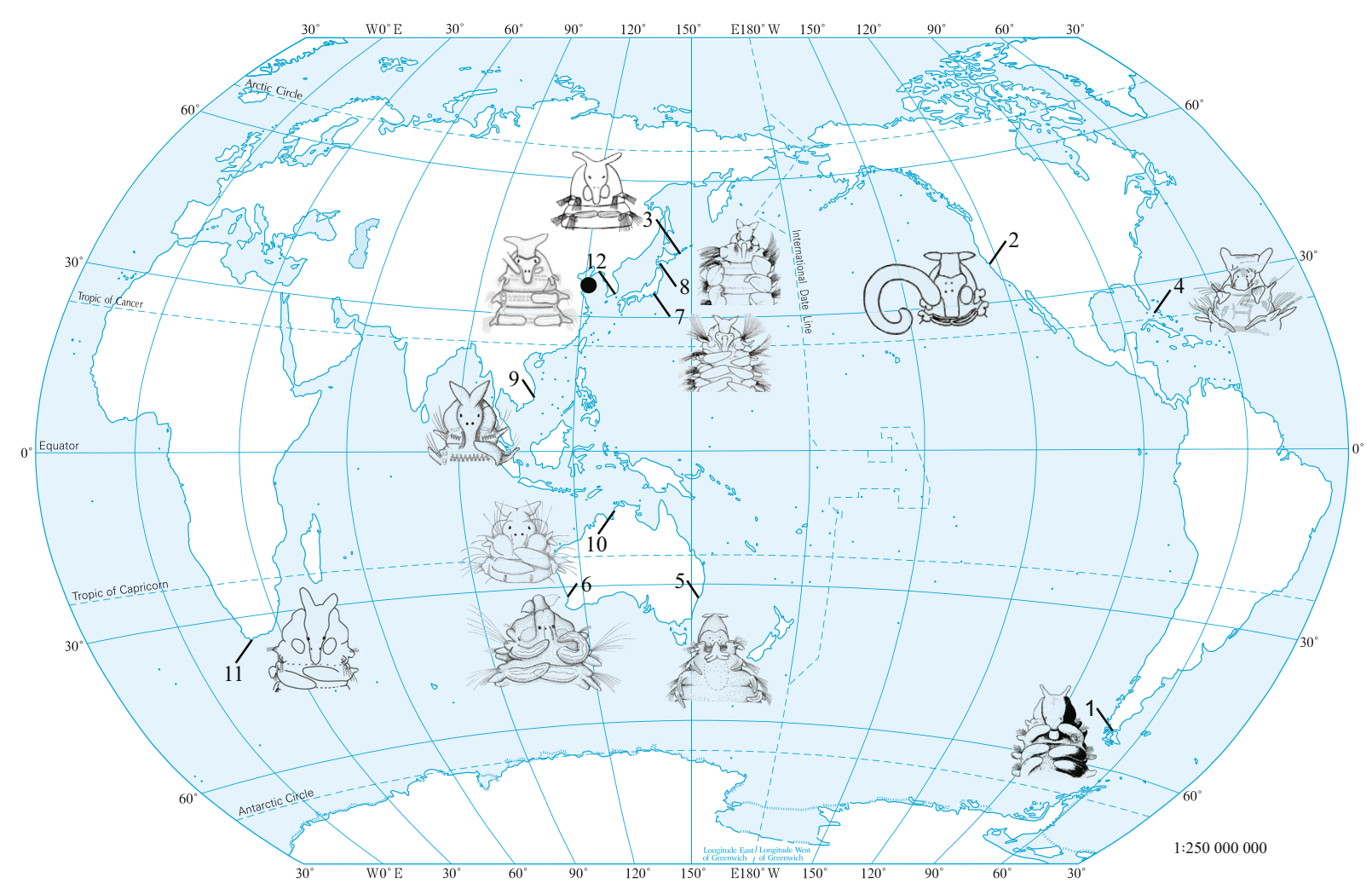

Fig.1 Type localities of Rhynchospio species (modified from Radashevsky et al. (2014))

-: the sampling site of $R$. aff. asiatica specimens in Qingdao Bay, Shandong Province, China (36 3 3'39.6"N, 120 19'15.6"E) used in this study. 1: $R$. glutaea (Ehlers, 1897), Punta Arenas, Strait of Magellan, Chile; 2: R. arenincola (Hartman, 1936), San Mateo County, California, USA; 3: $R$. asiatica (Chlebovitsch, 1959), Shikotan Island, South Kurile Islands; 4: R. inflata (Foster, 1971), Bimini Islands, Bahamas; 5: R. glycera (Blake and Kudenov, 1978), Burwood Beach, New South Wales, Australia; 6: R. australiana (Blake and Kudenov, 1978), Perth, West Australia, Australia; 7: R. tuberculata (Imajima, 1991), Sagami Bay, Honshu Island, Japan $\left(35^{\circ} 18^{\prime} 42^{\prime \prime} \mathrm{N}, 139^{\circ} 24^{\prime} 0^{\prime \prime} \mathrm{E}\right)$; 8: R. foliosa (Imajima, 1991), Usujiri Bay, Hokkaido Island, Japan; 9: R. nhatrangi (Radashevsky, 2007), Nha Trang Bay, Vietnam $\left(12^{\circ} 16^{\prime} 0^{\prime \prime} \mathrm{N}, 109^{\circ} 12^{\prime} 18^{\prime \prime} \mathrm{E}\right) ; 10: R$. darwini (Radashevsky, 2015), Fannie Bay, Northern Territory, Australia (12 $26^{\prime} 8.16^{\prime \prime} \mathrm{S}$, $\left.130^{\circ} 49^{\prime} 56.28^{\prime \prime} \mathrm{E}\right) ; 11$ : R. mzansi (Simon et al., 2019b), Gansbaai, South Africa (34³6'S, $\left.19^{\circ} 19^{\prime} \mathrm{E}\right) ; 12$ : R. aff. asiatica, Jinhae Bay, South Gyeongsang, South Korea. Map review No. GS(2016)1563.

morphological (Mackie, 1996; Blake and Arnofsky, 1999) and molecular (Abe et al., 2016) studies of the family, providing insights into the systematic relationships of the genera. However, the phylogenetic placement of some genera (e.g., Aonides, Carazziella, Microspio, Dispio, Tripolydora, and Pygospiopsis) has not been clarified, and in most genera the relationships among species have not been studied. This lack of phylogenetic studies is evident for spionids along the Chinese coasts: although there have been records of 17 genera and 69 species of spionids (Institute of Oceanology, Chinese Academy of Sciences and Liu, 2008; Zhou, 2008; Zhou and Li, 2009; Zhou et al., 2010b), only 9 species in 4 genera (Scolelepis, Polydora, Boccardiella, and Pseudopolydora) have been examined with molecular tools (Zhou et al., 2010a; Sato-Okoshi et al., 2013; Ye et al., 2015, 2017, 2019a, b).

Rhynchospio Hartman, 1936 is a genus of Spionidae characterized by a prostomium with fronto-lateral horns, paired branchiae from chaetiger 2 to near the posterior end, notochaetae all capillary and pygidium with more than two pairs of cirri (Foster, 1971; Radashevsky et al., 2014). A total of 13 species of Rhynchospio has been described, but only 11 of species are considered valid (Fig.1); R. microcera (Dorsey, 1977) and R. harrisae (Delgado-Blas and Díaz-Díaz, 2010) might belong to Microspio (Radashevsky et al., 2014). All adult Rhynchospio are considered hermaphrodites, and currently 5 species, i.e., $R$. glutaea (Ehlers, 1897), R. arenincola (Hartman, 1936), $R$. asiatica (Chlebovitsch, 1959), R. mzansi (Simon et al., 2019b), and an undescribed species $R$. aff. asiatica collected from South Korea are classified as belonging to the Rhynchospio glutaea complex characterized by having hooded hooks in neuropodia from chaetigers 9-18, tridentate both in juveniles and adults and pygidium with 2-5 pairs of cirri (Radashevsky, 2007a; Radashevsky et al., 2014). The other 7 species have quite distinct charateristics comparing to the species in Rhynchospio glutaea complex (See Taxonomic key to Rhynchospio species). 
There have been several records of Rhynchospio along the Chinese coast of the Yellow Sea, i.e., " $R$. arenincola" and " $R$. glutaea" from Qingdao Bay (Wu et al., 1993; Ji, 2012), and "R. glutaea" from Shidao Bay (Zhou, 2008). These Rhynchospio records are likely to be conspecific due to the short distance between Qingdao Bay and Shidao Bay $(\sim 210 \mathrm{~km})$, but neither detailed morphological or DNA barcoding data were available to determine their taxonomic statuses. At about the same latitude across the Yellow Sea from Jinhae Bay $\left(35^{\circ} \mathrm{N}\right)$ of South Korea, roughly $760 \mathrm{~km}$ from Qingdao, Radashevsky et al. (2014) found a species of the $R$. glutaea complex (temporally named " $R$. aff. asiatica") based on $5.15 \% \mathrm{~K} 2 \mathrm{P}$ genetic distance of the concatenated sequences of four genes (i.e., 16S rRNA, 18S rRNA, 28S rRNA, and Histone H3) from $R$. arenincola. Further studies are needed to check whether the Rhynchospio specimens from Qingdao and Jinhae are conspecific or not.

Brooding activities on the body of female spionids is currently known only in Streblospio and Rhynchospio, but whether the two genera use the same mechanism to transport their gametes to the dorsal brood region is unknown. In Streblospio, the gametes were suggested to be transported through coelom to the dorsal brood pouches formed by thinwalled, dorsolateral extensions of the coelom in middle segments (Collier and Jones, 1967). In Rhynchospio, Radashevsky (2007a) speculated that the elongated capillaries forming a "hatchery" in posterior chaetigers could keep the elongated introsperm there, thus improving fertilization efficiency. However, it is unknown how Rhynchospio transport mature gametes from the anterior and middle fertile segments to the posterior "hatchery".

Morphological and reproductive variations among spioniform genera had been used for uncovering their phylogenetic relationships (Sigvaldadóttir et al., 1997; Blake and Arnofsky, 1999). According to similar reproductive characteristics such as the occurrence of thick-enveloped oocyte, ect-aquasperm, and absence of egg capsule/mass in tube, twenty-one genera, including four spioniform genera (i.e., Poecilochaetus, Trochochaeta, Heterospio, and Uncispio) previously treated as independent families (i.e., Poecilochaetidae, Trochochaetidae, Longosomatidae, and Uncispionidae), had been grouped within the clade Nerininae in a cladistic analysis, which suggested that these four spioniform families should be considered as junior synonyms of Spionidae (Blake and Arnofsky, 1999). However, such analyses did not rule out the possibility of homoplasy in morphological and reproductive characteristics among genera of spionids, which may influence their clustering. A recent phylogenetic analysis conducted based on $16 \mathrm{~S}$ rRNA and $18 \mathrm{~S}$ rRNA gene sequences of spioniform genera, showed that Poecilochaetus and Trochochaeta were nested within the clade of subfamily Nerininae, which confirmed previous suggestions to place them into Spionidae (Abe and Sato-Okoshi, 2021). However, phylogenetic analysis based on more gene sequences, together with morphological characteristics, are still needed to make better understanding of their phylogenetic placements within Spionidae.

Previous phylogenetic studies had provided useful information on the selection of ingroups and outgroups in constructing credible phylogeny among spionids using nucleotide data. Besides Abe and Sato-Okoshi (2021), Rousset et al. (2007) and Struck et al. (2007, 2008) had also indicated close relationships between Spionidae and the two spioniform families Poecilochaetidae and Trochochaetidae, although these relationships were not well resolved. Also in these studies, several families (i.e., Sabellariidae, Sabellidae, and Serpulidae) of the order Sabellida, showed sister group relationships with Spionidae comparing to all other annelid families.

Another two families, i.e., Apistobranchidae and Longosomatidae, once believed to be a part of Spioniformia, however, had been found to be distantly related to Spionidae (Struck et al., 2008; Zrzavý et al., 2009; Blake and Maciolek, 2019; Blake and Petti, 2019). For Longosomatidae, morphological similarities had been found between its single genus Heterospio and cirratulids (Blake and Maciolek, 2019). Therefore, we followed these results to include Poecilochaetidae and Trochochaetidae as ingroups, and Sabellariidae, Sabellidae, and Serpulidae as outgroups in our phylogenetic analysis.

To explain the evolution of the morphological types of oocytes and sperm in spionids, two opposing hypotheses had been proposed. Söderström (1920) considered thin and smooth enveloped oocytes as a plesiomorphic characteristic and thick and sculptured envelope as a derived characteristic evolved in Spionidae. Hannerz (1956), on the contrary, suggested that thick-envelope oocytes might have evolved in a primary spionid and thin-envelope oocytes evolved in Spioninae due to reduction of the original thick envelope in connection with the evolution of brooding. Although the latter hypothesis had been supported by 
a comprehensive cladistic analysis of morphological and reproductive characteristics among genera of Spionidae (Radashevsky, 2007b), such analysis could not avoid the possible influences of homoplasy, and phylogenetic analysis using molecular data are needed to assess these hypotheses.

In this study, we presented the morphological features for Rhynchospio specimens collected from Qingdao Bay, China. Through observation of the ciliary beating in live specimens, we proposed a mechanism for transporting gametes from anterior and middle fertile segments to the brooding hatchery in posterior segments. By including DNA barcoding sequences for all available genera of spioniform annelids in our phylogenetic analyses, we aimed to determine the taxonomic statuses and phylogenetic placement of the Rhynchospio specimens from Qingdao Bay, and to study the evolution of reproduction of the family Spionidae. We also aimed to use nucleotide data, morphological and reproductive characteristics to make better estimates of the phylogenetic placements of two spioniform families (i.e., Poecilochaetidae and Trochochaetidae) recently included within Spionidae.

\section{MATERIAL AND METHOD}

\subsection{Sample collection and preservation}

Specimens of Rhynchospio were collected from the high intertidal zone of Qingdao Bay $\left(36^{\circ} 3^{\prime} 39.6^{\prime \prime} \mathrm{N}\right.$, $\left.120^{\circ} 19^{\prime} 15.6^{\prime \prime} \mathrm{E}\right)$, China, on November 2, 2014, June 18, 2015 and August 31, 2018. The sampling site was close to one of the two outfalls along the coast, located at the eastern side of Zhanqiao (the Pier, Supplementary Fig.S1). Sediments were washed through a $0.5-\mathrm{mm}$ sieve and the retained specimens were fixed either with $10 \%$ formaldehyde in seawater and later transferred into $75 \%$ ethanol for morphological analysis or directly in $95 \%$ ethanol for DNA extraction.

\subsection{Morphological analysis}

Parapodia and chaetae of chaetigers 1, 2, 4, 10, 20, 30 , and a posterior one were dissected with iris scissors and mounted on slides. Photographs of parapodia and chaetae, taken using a Sony DSCWX350 digital camera mounted on an Olympus CX31RTSF microscope, were used for line-drawings. Scanning electron microscopy (SEM) was used for detailed observation of cilia on palps and branchiae. The anterior part of specimen \#17 (Catalog No.:
XMU-Pol-2021-050) was dehydrated in pure ethanol, dried with the critical point drying method, mounted on conductive carbon adhesives, sputter coated with gold and observed with a LEO 1530 FESEM scanning electron microscope.

\subsection{Molecular-based phylogenetic analyses}

2.3.1 DNA extraction, PCR amplification, and sequencing

Two specimens (XMU-Pol-2021-049, XMUPol-2021-050) preserved in 95\% ethanol were used for DNA extraction. The posterior segments were dissected, and the genomic DNA was extracted using a DNeasy blood \& tissue kit (QIAGEN, Hilden, Germany). Four primer pairs were used to amplify corresponding genes, i.e., 16SAR-L and 16SBR-H for the mitochondrial 16S rRNA gene (Palumbi et al., 1991); 1F and 9R for the nuclear 18S rRNA gene (Giribet et al., 1996); NLF184/21 and D3aR for the nuclear 28S rRNA gene (Lenaers et al., 1989; Van der Auwera et al., 1994) and H3af and H3ar for the Histone H3 gene (Colgan et al., 1998). The PCR protocol followed Zhang et al. (2018). PCR products were purified using a Zymoclean ${ }^{\mathrm{TM}}$ Gel DNA Recovery Kit and sequenced using Sanger sequencing at BGI Hong Kong.

\subsubsection{Phylogenetic analyses}

The sequences of these four genes of 24 spioniform genera, including Trochochaeta and Poecilochaetus, as well as outgroups (i.e., Serpulidae, Sabellidae, and Sabellariidae) deposited in GenBank (https:/www. ncbi.nlm.nih.gov/) were downloaded for phylogenetic analyses (Table 1). Taxa with no DNA sequences available, such as the genera Amphipolydora, Carazziella, Laubieriellus, Lindaspio, Pygospiopsis, Scolecolepides, and Tripolydora in Spionidae and the family Uncispionidae, were not included in the analyses. Two families previously considered as members of Spioniformia, Apistobranchidae and Longosomatidae were excluded from the phylogenetic analyses due to their distant relationships from the spionid clade (Struck et al., 2008; Zrzavý et al., 2009; Blake and Maciolek, 2019; Blake and Petti, 2019). The four gene sequences were aligned using the MUSCLE algorithm implemented in the software Mesquite (Edgar, 2004), and poorly aligned positions were removed with the Gblocks Server (http:// molevol.cmima.csic.es/castresana/Gblocks_server.html). The four trimmed genes were concatenated using 


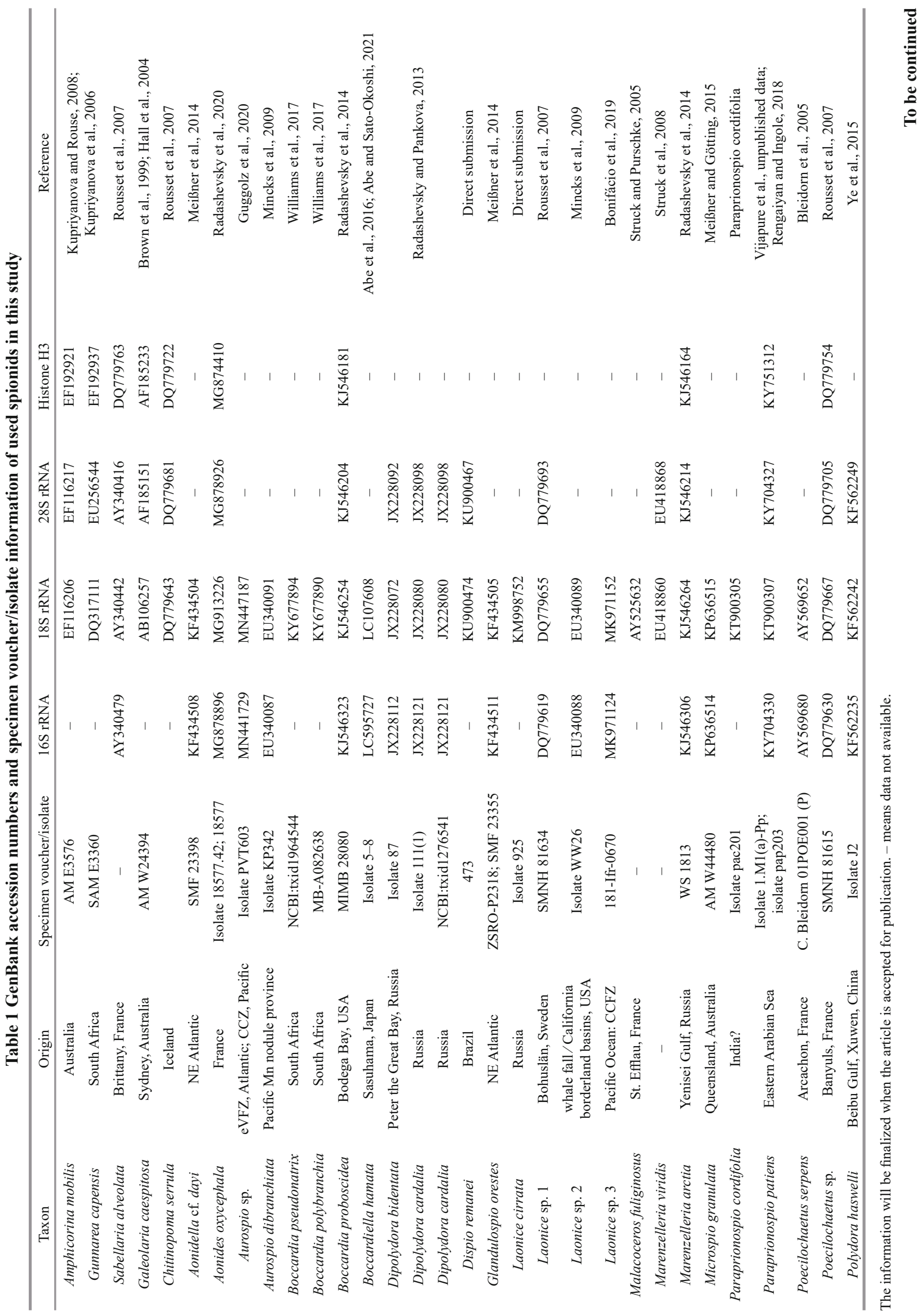




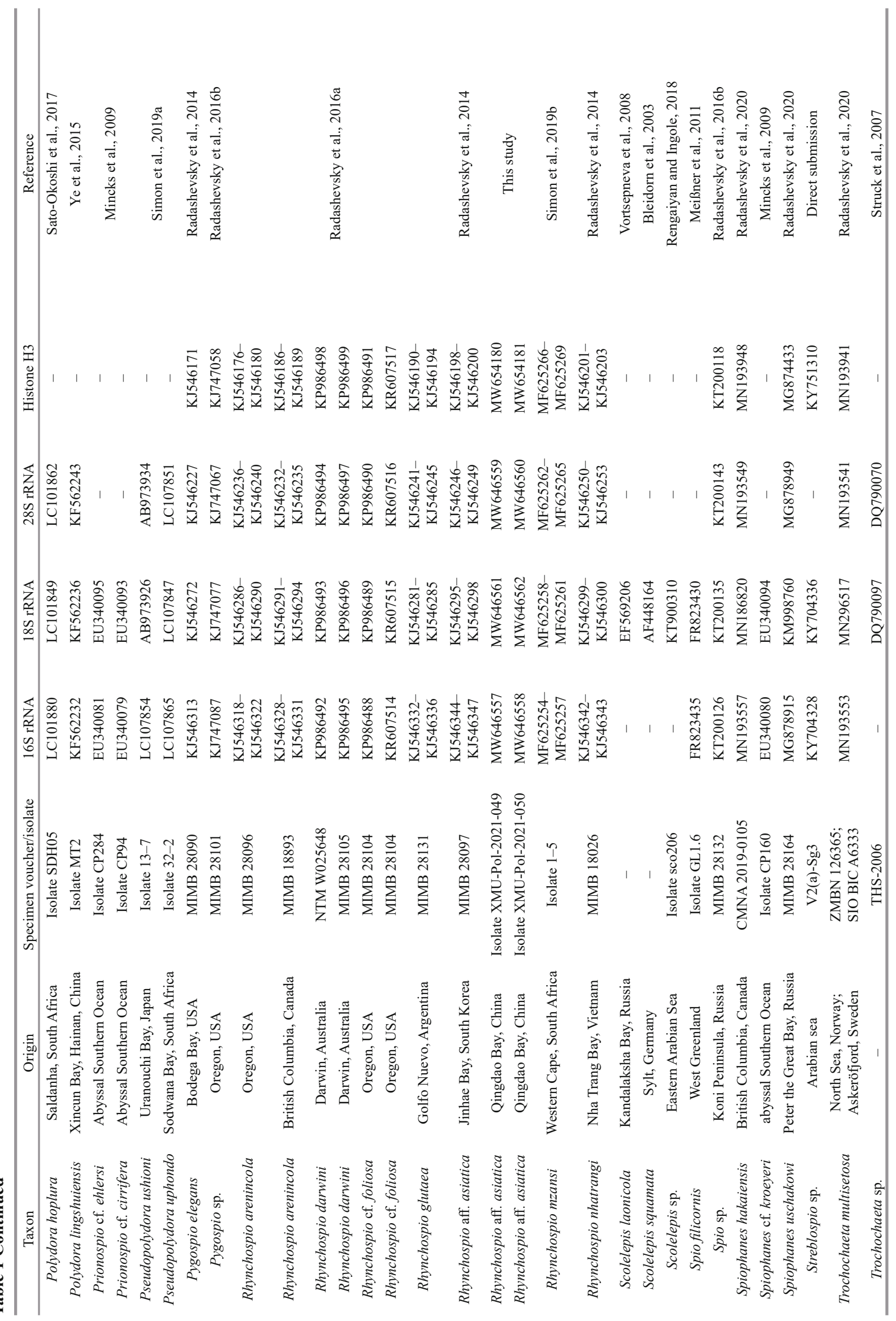


SequenceMatrix v.1.7.8 (Vaidya et al., 2011). The K2P genetic distances (Kimura, 1980) between Rhynchospio species was estimated based on each gene sequence (i.e., 246-bp 16S rRNA, 1493 -bp 18S rRNA, 292-bp 28S rRNA, 289-bp Histone H3) and their concatenated sequence (2 $320 \mathrm{bp}$ ) using MEGA X (Kumar et al., 2018). Two phylogenetic analyses were conducted using the Maximum Likelihood (ML) and Bayesian Inference (BI) approaches. One analysis focused on the phylogeny among Rhynchospio species, which were carried out based on the concatenated sequences (2 $444 \mathrm{bp})$ of partial $16 \mathrm{~S}$ rRNA (294 bp), 18S rRNA (1 502 bp), 28S rRNA (323 bp), Histone H3 (325 bp) genes of Rhynchospio, Boccardia, and Pygospio rooted with Marenzelleria sequences. The other analysis focused on the phylogeny among spioniform genera, which were constructed based on the concatenated sequences (2 $483 \mathrm{bp}$ ) of partial 16S rRNA (302 bp), 18S rRNA (1 $535 \mathrm{bp}$ ), 28S rRNA (321 bp) and Histone H3 (325 bp) genes of Spionidae, Sabellidae, and Sabellariidae rooted with Serpulidae sequences. The best fitting nucleotide-substitution model was evaluated using jModelTest v.2.1.1 (Darriba et al., 2012). Specifically, the ML analysis was conducted using the "thorough bootstrap" option with 1000 bootstrap replicates via raxmlGUI v.2.0.0 (Edler et al., 2021). The BI analysis was conducted using MrBayes v.3.2.0 with corresponding models used in the ML analyses and Markov Chains were run for 10000000 generations with topologies being sampled every 1000 generations (Ronquist and Huelsenbeck, 2003). The first $25 \%$ trees were discarded as "burn-in" and software Tracer v.1.7.1 was used to check for the convergence of the trees (Rambaut et al., 2018).

\subsection{Morphological and reproductive characteristics of spionids}

To study the evolution of morphological and reproductive characteristics with reference to the molecular-based phylogenetic analyses, the following characteristics were compiled for all the 54 analyzed spioniform species. There are morphological groups: Group A: heavy spines present in chaetiger 5 and fullsized branchiae starting from chaetiger 7 , with exceptions in four genera: branchiae in Boccardia and Boccardiella starting from chaetiger 7 in juveniles but chaetiger 2 in adults; branchiae in Dipolydora starting from chaetiger 7-10; though not included in the phylogenetic analysis, adult Tripolydora has full- sized branchiae from chaetiger 7 , but short ones in chaetigers 2-6. Group B: without heavy spines and branchiae starting from chaetiger 1 or 2 to near the end. Group C: branchiae starting from chaetiger 1,2, or 3 , on a certain number of anterior segments. Group D: without branchiae in adults. Types of sperm (i.e., Ect: ect-aquasperm; and Int: introsperm). Types of oocyte (i.e., type I: oocytes with thick envelopes bearing numerous vesicles; type II: oocytes with thick envelopes without vesicles; and type III: oocytes with thin envelopes without vesicles). Reproductive patterns (i.e., Bro: brooding; and Nbro: non-brooding). Egg protection modes (i.e., cap I: hollow cylinder attached to tube; cap II: beadlike string capsules attached to the wall of tube; cap III: series of single capsules; intub: egg cocoon/egg mass in tube; onfem: on the body of female; eem: external egg masses/ external jellylike cocoon; and Brsp: broadcast spawning into water column). Types of larval development (i.e., Pla: planktotrophic; Lec: lecithotrophic; and Dir: direct development). The morphological groups were created by the authors in this study and the other groups mentioned here were present on different studies (Jamieson and Rouse, 1989; Blake and Arnofsky, 1999; Radashevsky et al., 2016a, 2018; Blake et al., 2020).

\section{RESULT}

\subsection{Systematics}

Family Spionidae Grube, 1850

Genus Rhynchospio Hartman, 1936

Type species: Rhynchospio arenincola Hartman, 1936, by original designation. Type locality: San Mateo County, central California, USA.

Diagnosis (emended from Blake et al., 2020): Prostomium with fronto-lateral horns, caruncle variously developed; eyespots two pairs; occipital antenna absent. Branchiae from chaetiger 2 to near the end, free from dorsal lamellae or only fused basally. Notochaetae all capillary. Neurochaetae capillaries, hooded hooks, and sabre chaetae. Pygidium with cirri or lobes.

Remark: Blake et al. (2020) introduced the eyespots of Rhynchospio as present or absent, but we found that 10 of the 11 Rhynchospio species have 4 eyespots, while $R$. glutaea has only 2 after the original description.

\section{Rhynchospio aff. asiatica}

(Figs.1-5, Supplementary Fig.S1, Tables 1-3, Supplementary Table S1; Supplementary Videos S1-S4) 

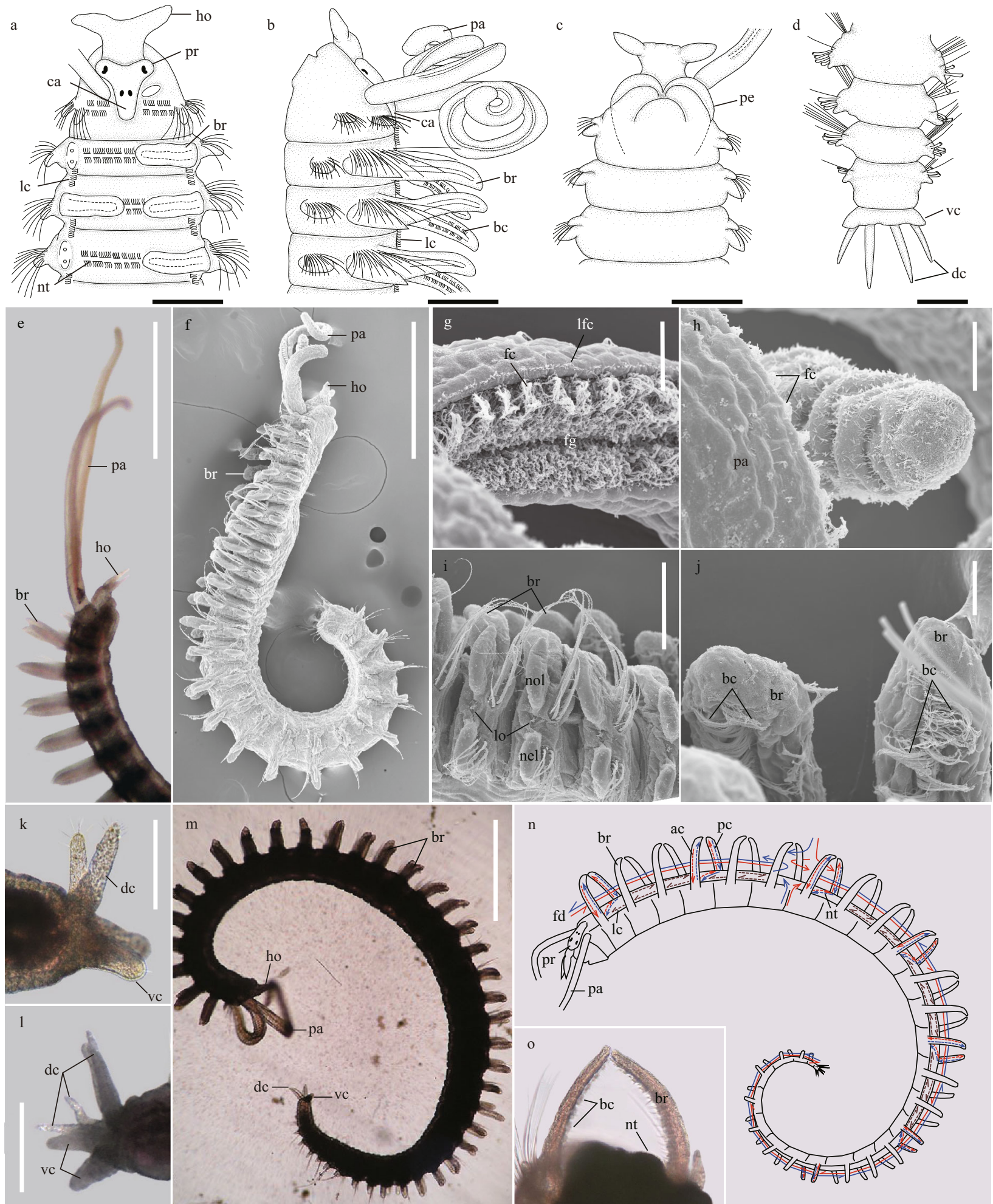

$\mathrm{pc}$

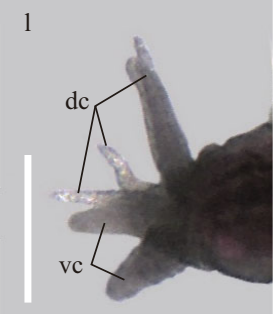

Fig.2 Morphology of Rhynchospio aff. asiatica

a. anterior end, dorsal view; b. same, lateral view; c. same, ventral view; d. posterior end, ventral view; e-j. specimen \#17; e. anterior end, lateral view; f same, SEM; g. middle part of palp, frontal view; h. distal end of palp; i. segments 4-7, lateral view; j. branchiae of segments $3-4$; k. pygidium with 2 ventral cirri and 2 dorsal cirri; 1 . pygidium with 2 ventral cirri and 4 dorsal cirri; $\mathrm{m}$. lateral view of a whole worm; $\mathrm{n}$. schematic drawing showing the water flow direction (solid line) and cilia wave direction (dashed line); o. a dorsal cilia ring formed by a pair of branchia and the dorsum in anterior segments. Scale bars: g, h, j: $20 \mu \mathrm{m} ; \mathrm{d}, \mathrm{i}, \mathrm{k}, \mathrm{l}: 100 \mu \mathrm{m} ; \mathrm{a}-\mathrm{c}: 200 \mu \mathrm{m} ; \mathrm{e}, \mathrm{f}, \mathrm{m}: 500 \mu \mathrm{m}$. Abbreviations: ac: anterior row of cilia; bc: branchial cilia; br: branchiae; ca: caruncle; dc: dorsal cirri; fc: frontal cilia; fd: water flow directions; fg: food groove; ho: fronto-lateral horns; lc: intersegmental longitudinal cilia; lfc: lateral-frontal cilia; lo: lateral ciliated organ; nel: neuropodial postchaetal lamellae; nol: notopodial postchaetal lamellae; nt: double-row nototrochs; pa: palps; pc: posterior row of cilia; pe: peristomium; pr: prostomium; vc: ventral cirri. 

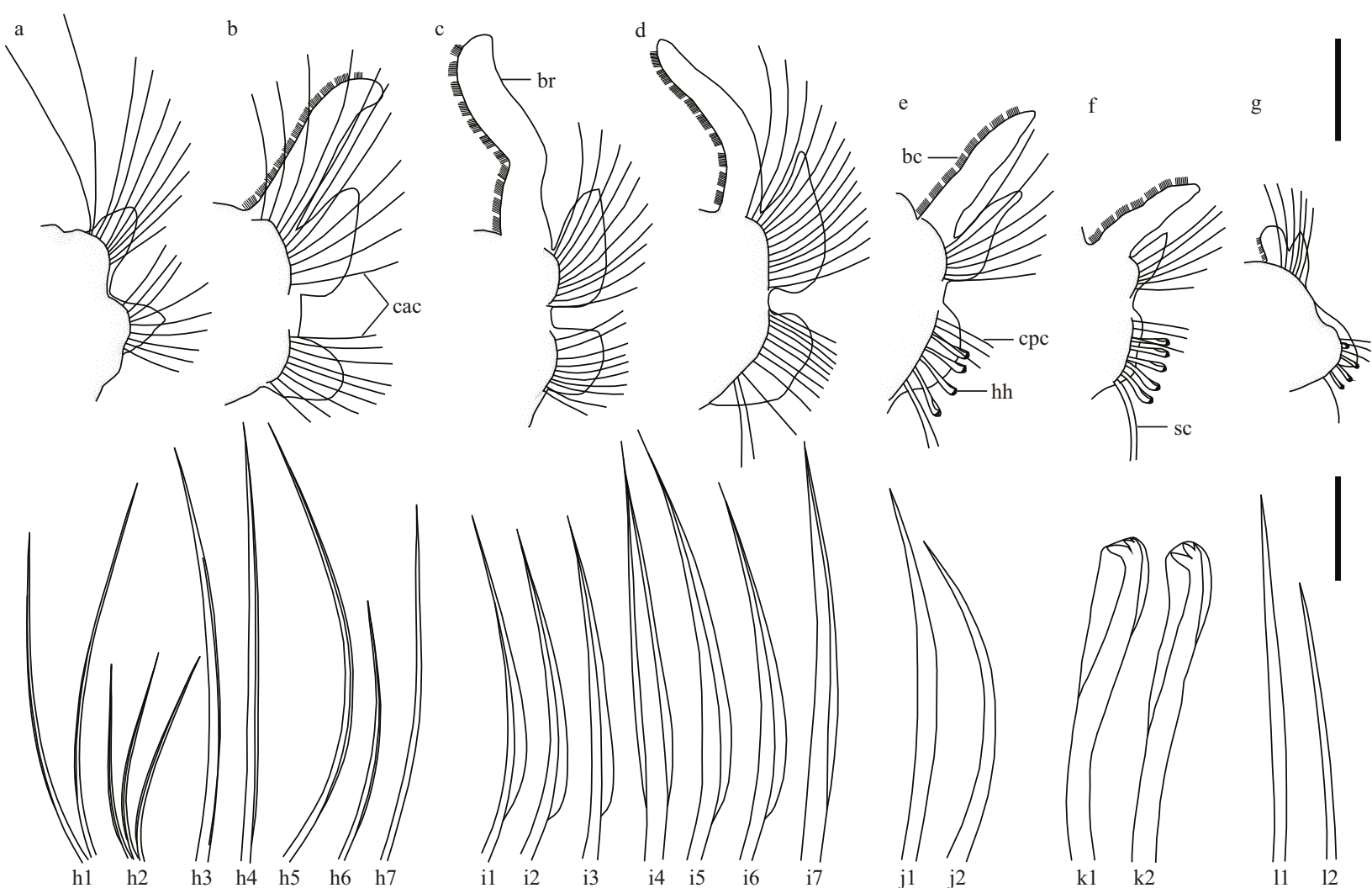

Fig.3 Parapodia and chaetae of Rhynchospio aff. asiatica

a-g. parapodia; a. chaetiger 1, anterior view; b. chaetiger 2, anterior view; c. chaetiger 4, anterior view; d. chaetiger 10, anterior view; e. chaetiger 20, anterior view; f. chaetiger 30, anterior view; g. posterior chaetiger, anterior view; h-1. chaetae; h. capillary chaetae in posterior rows of chaetigers; h1. chaetiger 1, notopodium; h2. chaetiger1, neuropodium; h3. chaetiger 2, notopodium; h4. chaetiger 2, neuropodium; h5. chaetiger 5, notopodium; h6. chaetiger 20, notopodium; h7. chaetiger 30, notopodium; i. chaetae in anterior rows of chaetigers; i1. chaetiger 1, notopodium; i2. chaetiger 1, neuropodium; i3. chaetiger 2, neuropodium; i4. chaetiger 3, notopodium; i5. chaetiger 5, notopodium; i6. chaetiger 10, neuropodium; i7. chaetiger 15 , neuropodium; j. sabre chaetae; j1. chaetiger $20 ; j 2$. posterior chaetiger; $\mathrm{k}$. hooded hooks in the posterior rows of neuropodia; $\mathrm{k} 1$. chaetiger 16 ; $\mathrm{k} 2$. chaetiger $20 ; 1$. companion chaetae in the anterior rows of neuropodia; 11. chaetiger 17; 12. chaetiger 20. Scale bars: h3, h4, i-1: $20 \mu \mathrm{m} ; \mathrm{h} 1$, h2, h5-h7: $50 \mu \mathrm{m}$; a-g: $100 \mu \mathrm{m}$. Abbreviations: bc: branchial cilia; br: branchiae; cac: capillary chaetae; cpc: companion chaetae; hh: hooded hooks; sc: sabre chaetae.

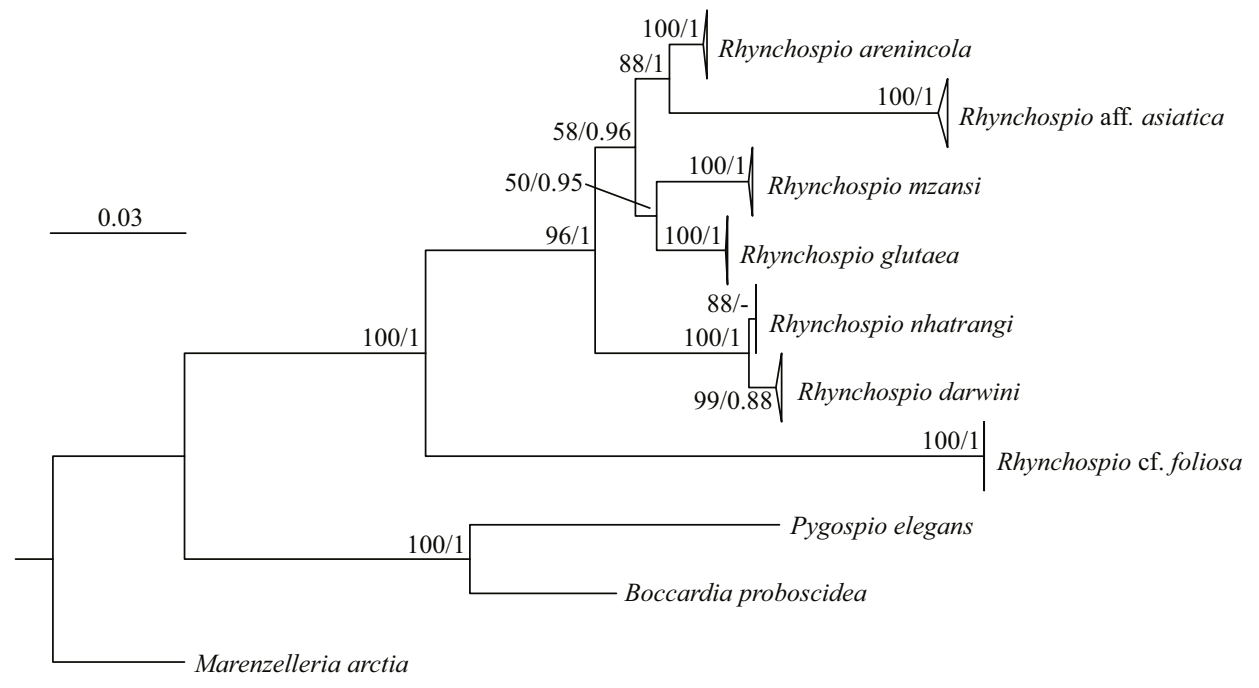

Fig.4 Phylogenetic tree reconstructed with Maximum Likelihood (ML) and Bayesian Inference (BI) methods

The tree was constructed based on the concatenated sequences (2 $444 \mathrm{bp}$ ) of partial 16S rRNA (294 bp), 18S rRNA (1 502 bp), 28S rRNA (323 bp), and Histone H3 (325 bp) genes of Boccardia, Pygospio, and Rhynchospio rooted with Marenzelleria sequences. Values of robustness were calculated from ML and BI analyses. Only bootstrap (BS) values $\geq 50$ and Bayesian posterior probabilities (BPP) values $\geq 0.7$ are shown at nodes. -: node absent in BI. Information of spionids used is listed in Table 1 . Scale bar indicates the number of substitutions per site. 


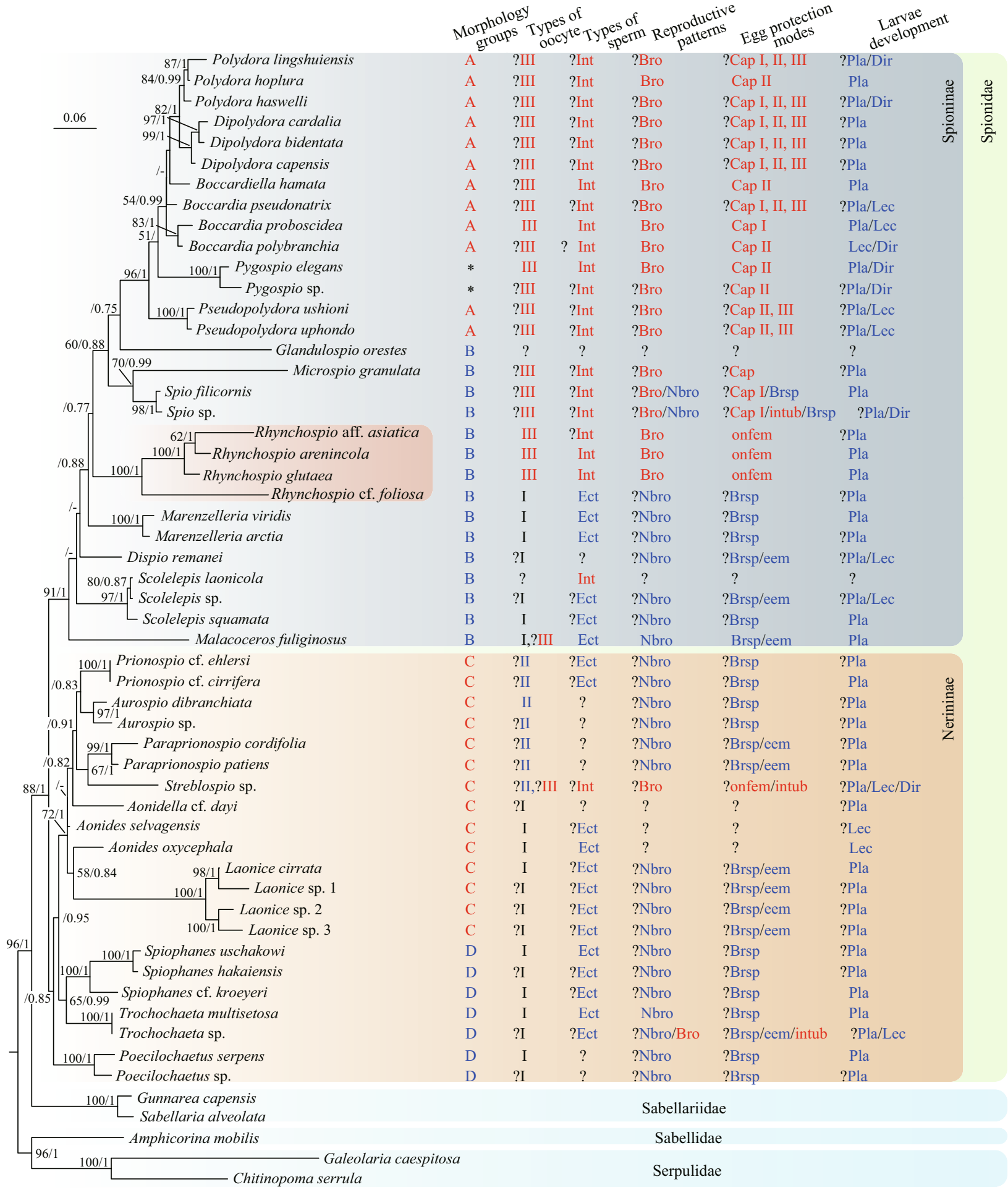

Fig.5 Phylogenetic tree reconstructed with Maximum Likelihood (ML) and Bayesian Inference (BI) methods

The tree was constructed based on the concatenated sequences (2 $483 \mathrm{bp}$ ) of partial 16S rRNA (302 bp), 18S rRNA (1 535 bp), 28S rRNA (321 bp), and Histone H3 (325 bp) genes of Sabellidae, Sabellariidae, and Spionidae rooted with Serpulidae sequences. Values of robustness were calculated from ML and $\mathrm{BI}$ analyses. Only bootstrap (BS) values $\geq 50$ and Bayesian posterior probabilities (BPP) values $\geq 0.7$ are shown at nodes. -: node absent in BI. Information of spionids and the remaining taxa used is listed in Table 1. The scale bar indicates the number of substitutions per site. For morphological groups and reproductive characteristics refer to "Material and Methods". * Pygospio bears no spines with its branchiae starting from chaetiger 10. Question marks before characteristics indicate that such classification has not been reported in this species, but it has been noted in other species of the same genus.

Materials examined: One specimen (XMUPol-2021-050) collected on 2 November 2014, three specimens (XMU-Pol-2021-034, XMU-Pol-2021-035, and XMU-Pol-2021-036) collected on 18 June 2015, 
Table 2 Major morphological characteristics for 17 specimens of Rhynchospio aff. asiatica (XMU-Pol-2021-034 to XMUPol-2021-050) used in this study

\begin{tabular}{|c|c|c|c|c|c|c|c|c|c|}
\hline Taxa & Catalog No. & $\begin{array}{l}\text { Length } \\
(\mathrm{mm})\end{array}$ & $\begin{array}{l}\text { Width } \\
(\mathrm{mm})\end{array}$ & $\begin{array}{c}\text { Total No. of } \\
\text { chaetigers }\end{array}$ & $\begin{array}{l}\text { First chaetiger with } \\
\text { hooded hooks }\end{array}$ & $\begin{array}{c}\text { Chaetigers } \\
\text { with oocytes }\end{array}$ & Pygidial cirri ${ }^{\dagger}$ & $\begin{array}{l}\text { Collection } \\
\text { date }\end{array}$ & Preservation \\
\hline Specimen \#1 & XMU-Pol-2021-034 & 7.5 & 0.5 & 51 & 16 & $17-33$ & $2+3$ & 2015.6.18 & Formalin \\
\hline Specimen \#2 & XMU-Pol-2021-035 & 9.1 & 0.5 & 59 & 16 & $17-39$ & - & 2015.6 .18 & Formalin \\
\hline Specimen \#3 & XMU-Pol-2021-036 & 8.5 & 0.5 & 59 & 17 & $17-33$ & - & 2015.6 .18 & Formalin \\
\hline Specimen \#4 & XMU-Pol-2021-037 & 10.9 & 0.6 & 54 & 15 & - & $2+4$ & 2018.8 .31 & Formalin \\
\hline Specimen \#5 & XMU-Pol-2021-038 & 8.3 & 0.6 & 51 & 16 & $16-26$ & $2+3$ & 2018.8 .31 & Formalin \\
\hline Specimen \#6 & XMU-Pol-2021-039 & 7.1 & 0.5 & 47 & 15 & - & $2+4$ & 2018.8 .31 & Formalin \\
\hline Specimen \#7 & XMU-Pol-2021-040 & 7.3 & 0.5 & 40 & 16 & - & $2+3$ & 2018.8 .31 & Formalin \\
\hline Specimen \#8 & XMU-Pol-2021-041 & 10.3 & 0.5 & 54 & 16 & - & $2+4$ & 2018.8 .31 & Formalin \\
\hline Specimen \#9 & XMU-Pol-2021-042 & 7.1 & 0.4 & 45 & 14 & - & $2+4$ & 2018.8 .31 & Formalin \\
\hline Specimen \#10 & XMU-Pol-2021-043 & 4.3 & 0.5 & 38 & 15 & - & $2+3$ & 2018.8 .31 & Formalin \\
\hline Specimen \#11 & XMU-Pol-2021-044 & 7.3 & 0.5 & 50 & 15 & - & $2+4$ & 2018.8 .31 & Formalin \\
\hline Specimen \#12 & XMU-Pol-2021-045 & 7.8 & 0.6 & 51 & 15 & - & $2+4$ & 2018.8 .31 & Formalin \\
\hline Specimen \#13 & XMU-Pol-2021-046 & 6.3 & 0.6 & 44 & 16 & - & $2+2$ & 2018.8 .31 & Formalin \\
\hline Specimen \#14 & XMU-Pol-2021-047 & 6.8 & 0.7 & 50 & 16 & - & $2+2$ & 2018.8 .31 & Formalin \\
\hline Specimen \#15 & XMU-Pol-2021-048 & 8.9 & 0.5 & 56 & 16 & $16-31$ & $2+3$ & 2018.8 .31 & Formalin \\
\hline Specimen \#16 & XMU-Pol-2021-049 & 8.1 & 0.5 & 55 & 15 & - & $2+4$ & 2018.8 .31 & Ethanol \\
\hline Specimen \#17 & XMU-Pol-2021-050 & 6.2 & 0.5 & 43 & 14 & - & $2+4$ & 2014.11 .2 & Ethanol \\
\hline
\end{tabular}

+ : the formula indicates "the number of ventral cirri" + "the number of dorsal cirri". - means data not available.

and thirteen specimens (XMU-Pol-2021-037, XMUPol-2021-038, XMU-Pol-2021-039, XMU-Pol-2021040, XMU-Pol-2021-041, XMU-Pol-2021-042, XMUPol-2021-043, XMU-Pol-2021-044, XMU-Pol-2021045, XMU-Pol-2021-046, XMU-Pol-2021-047, XMUPol-2021-048, and XMU-Pol-2021-049) collected on 31 August 2018 from an intertidal muddy sand beach in Qingdao Bay, Shandong, China (Table 2).

Description: Body slender, anterior part slightly wider and taper off to the end (Fig.2a-d). Prostomium T-shaped, bearing two conical latero-frontal horns (Fig.2a); caruncle not elevated above prostomium, reaching chaetiger 1 (Fig.2a \& b); nuchal organs not observed; eyespots two pairs arranged in inverted trapezoid, small, brownish in color, anterior eyes crescent, twice as large as posterior ones (Fig.2a). Occipital tentacle absent (Fig.2a). Palps extending backward to chaetiger 9, with ventral longitudinal food groove along whole length (Fig.2b, e-h).

Branchiae flattened, present from chaetiger 2 to near the posterior end (Fig.2e \& $\mathrm{m}$ ), free from notopodial postchaetal lamellae (Fig.3b-g); branchiae longer, wider in anterior and middle chaetigers, shorter, narrower in posterior chaetigers (Fig.2a, b, e, $\mathrm{m})$. Paired branchiae bending towards each other in each segment, with branchial surfaces oriented parallel to longitudinal body axis (Fig.2a, i, j). Two parallel rows of branchial cilia present along inner surface of each branchia (Fig.2b, j, n), together with double-row nototrochs, forming a ciliary ring on dorsum of each segment (Fig.2a, b, o). Metameric nuchal organs not observed. Short bands of cilia present between segments on dorsolateral edges (Fig.2a \& b). Notopodial and neuropodial postchaetal lamellae of chaetiger 1 triangular, small (Fig.3a); notopodial postchaetal lamellae larger from chaetiger 2 , subtriangular with terminal tips, becoming smaller from middle to posterior chaetigers (Fig.3b-g). Neuropodial postchaetal lamellae oval shaped from chaetiger 2, becoming wider and shorter in middle chaetigers, and obtuse triangular in posterior chaetigers (Fig.3b-g).

Anterior chaetigers with two rows of capillary chaetae in both notopodia and neuropodia (Fig.2i). Chaetae in anterior row with wide unilateral or bilateral limbation and fine granulation on distal part of shaft (Fig.3i). Chaetae in posterior row longer and thinner, without granulation (Fig.3h). Hooded hooks present only in neuropodia, 3-7 in posterior row (Fig.3e-g), from chaetiger $14-17$ to posterior end (Fig.3e-g), with one main fang and two smaller upper teeth situated one above the other (Fig.3k). Sabre 
chaetae without limbation, 2-3 per rami, present below hooded hooks from chaetigers 14-17 (Fig.3e-g, j). Companion chaetae without limbation, 2-4 in number, present in anterior row of hooded hooks (Fig.3e-g, 1).

Pygidium with one pair of stumpy ventral cirri and 1 to 2 pairs of thinner and longer dorsal cirri in most specimens (Fig.2d, k, 1).

Dorsal tunnel: Observations of live specimens of Rhynchospio collected from Qingdao revealed a dorsal tunnel for the first time (Fig.2m-o). On most segments, a somewhat closed circle is formed by paired branchiae and the dorsum (Fig.2o; Supplementary Video S1). All these circles together form a dorsal tunnel. Two rows of parallel cilia are present along the inner side of branchiae and the dorsum, forming two parallel ciliary rings on each segment (Fig. $2 \mathrm{j} \& \mathrm{n}$ ). The anterior ciliary band beats backward and the posterior ciliary band beats forward, creating a dexioplectic metachronal wave with the effective beating of cilia being to the right of the wave (Supplementary Videos S2 \& S3). The same pattern of cilia beating has been widely observed in annelids (Knight-Jones, 1954). When the anterior row of cilia in all segments beats in the same direction from anterior to posterior, it forms a backward water flow; when the posterior row of cilia in each segment beats from posterior to anterior direction, it forms a forward waterflow (Supplementary Video S3). By coordinating the beating of the anterior and posterior ciliary bands, the worm can transport small particles along the dorsal tunnel from anterior to posterior, or vice versa (Supplementary Videos S3 \& S4).

Ecology: The specimens of Rhynchospio aff. asiatica examined in this study live in muddy sand sediment in the high intertidal zone of Qingdao Bay, a habitat encountering fluctuations in environmental conditions created by inundation of tides and discharge of domestic sewage (Supplementary Fig. S1). Du et al. (2011) indicated higher sedimentary organic content (1.81\% vs. $0.44 \%)$ in the studied intertidal zone than that in offshore zone. In addition, as a tourist spot, the study site encounters frequent human disturbances including trampling and clam digging especially in the summer. The abundance of Rhynchospio in the study site varied seasonally from high at 21522 inds. $/ \mathrm{m}^{2}$ in August to low at 308 inds./ $\mathrm{m}^{2}$ in May (Wang, 2015).

K2P genetic distances: Among the Rhynchospio species compared, the Qingdao Bay sequences are most closely related to those of $R$. aff. asiatica from
Jinhae Bay, South Korea. The K2P genetic distances between the two populations was only $0.41 \%$ for $16 \mathrm{~S}$ rRNA, $0.12 \%$ for $18 \mathrm{~S}$ rRNA, 0 for $28 \mathrm{~S}$ rRNA, $0.88 \%$ for Histone $\mathrm{H} 3$, and $0.19 \%$ for the concatenated sequences. These small genetic distances clearly indicated that the Qingdao population is conspecific to the South Korea population, which will be described as a new species (Vasily I. Radashevsky, personal communication). Among the described Rhynchospio species, $R$. arenincola has the smallest average K2P distances with $R$. aff. asiatica, i.e., $6.10 \%$ for the concatenated sequences of four genes, $20.02 \%$ for $16 \mathrm{~S}$ rRNA, $4.50 \%$ for $18 \mathrm{~S}$ rRNA, $8.44 \%$ for $28 \mathrm{~S}$ rRNA, and $2.74 \%$ for Histone H3. Other species are more distantly related (Supplementary Table S1).

\subsection{Phylogeny and morphology in spionids}

Phylogenetic analysis (Fig.4) shows that all Rhynchospio aff. asiatica specimens collected from Qingdao and Jinhae form a well-supported clade $(\mathrm{BS}=100 ; \mathrm{BPP}=1)$ that is sister to $R$. arenincola from California $(\mathrm{BS}=88 ; \quad \mathrm{BPP}=1)$; and all seven Rhynchospio species included in the analysis form a monophyletic clade $(\mathrm{BS}=100 ; \mathrm{BPP}=1)$. All spionids form a single clade $(\mathrm{BS}=88 ; \mathrm{BPP}=1)$ that is sister to Sabellariidae $(B S=96 ; \quad B P P=1)$. Two clades are detected within spionids: clade 1 (here referred to as Spioninae) includes Polydora, Dipolydora, Boccardiella, Boccardia, Pygospio, Pseudopolydora, Glandulospio, Microspio, Spio, Rhynchospio, Marenzelleria, Dispio, Scolelepis, and Malacoceros $(\mathrm{BS}=91 ; \mathrm{BPP}=1)$; clade 2 (here referred to as Nerininae) includes Prionospio, Aurospio, Paraprionospio, Streblospio, Aonidella, Aonides, Laonice, Spiophanes, Trochochaeta, and Poecilochaetus, although with low support values ( $\mathrm{BS}=46 ; \mathrm{BPP}=0.85)$. Morphologically, all taxa within morphology group A, together with Pygospio, form a single clade $(\mathrm{BS}=96 ; \mathrm{BPP}=1)$, while all taxa within morphology group B showed paraphyletic relationships (excluding Spio and Microspio). All taxa within morphology group $\mathrm{C}$ form a single clade $(\mathrm{BS}=72 ; \mathrm{BPP}=1)$, while Poecilochaetus within morphology group D showed paraphyletic relationship with the group formed by Spiophanes and Trochochaeta $(\mathrm{BS}=65 ; \mathrm{BPP}=0.99)$.

\subsection{Reproductive and larval characteristics in spionids}

Despite there are ambiguous or missing information in reproductive and larval characteristics, distinct 
clusters corresponding to the phylogenetic tree could be noted within each characteristic (Fig.5). Four clusters of spionids according to types of oocytes include a cluster corresponding to type III, a cluster corresponding to type II, and two separate clusters corresponding to type I at the basal positions of Spioninae and Nerininae. Two exceptions in Malacoceros and Streblospio are noted with both thick- and thin-enveloped oocytes. Three characteristics (i.e., types of sperm, reproductive patterns and egg protection modes) are basically divided into two clusters, i.e., one cluster includes taxa corresponding to those with oocyte type III, while the other cluster including other spioniform taxa excluding some species of Trochochaeta, Streblospio, and an ectoparasitic spionid Scolelepis laonicola. Almost all spioniform taxa have planktotrophic larval development, while lecithotrophic and direct development modes are only found in about $1 / 4$ to $1 / 3$ of the analyzed genera in this study.

\section{DISCUSSION}

Rhynchospio aff. asiatica, originally recorded from Jinhae, South Korea, is characterized by having sperm in chaetigers 11-14, and oocytes starting from chaetiger 16 (Radashevsky et al., 2014). This species described based on individuals from Jinhae will be formally named in a manuscript submitted for publication (Vasily I. Radashevsky, personal communication). Our Rhynchopsio individuals from Qingdao are characterized by having smooth laterofrontal horns, four trapezoidally arranged eyespots, neuropodial hooded hooks starting from chaetigers 14-17 to posterior end, sperm in chaetigers 11-14, oocytes from chaetigers $16-17$ to chaetigers $26-39$, and 2-3 pairs of pygidial cirri. Morphologically, the specimens from Qingdao could be classified as belonging to the Rhynchospio glutaea complex, and further identified as $R$. aff. asiatica due to their similarity in the distribution of sperm and oocytes along segments (Radashevsky et al., 2014). Molecular results support the two populations of Rhynchospio to be conspecific by showing quite small inter-population K2P distances.

Although thirteen Rhynchospio species including an unnamed species $R$. cf. folios $a$ have been recorded, molecular data are only available for seven species (Radashevsky et al., 2014, 2016a; Simon et al., 2019b; this study), and the phylogenetic placements of the other six species (i.e., R. asiatica, R. foliosa,
$R$. tuberculata, $R$. australiana, $R$. glycera, and $R$. inflata) are still undetermined. Based on morphological characteristics, three Rhynchospio species, i.e., $R$. australiana, $R$. glycera, and $R$. inflata, have apparent divergences with $R$. foliosa/R. cf. foliosa, the two tropical species (i.e., $R$. darwini and R. nhatrangi), and those in the Rhynchospio glutaea complex, Specifically, R. australiana bears a pair of broad horns (rather than digitiform in the R. glutaea complex), lacking (rather than possessing) notopodial capillaries on chaetiger 1, plate-like (rather than cirriform) pygidium, and perpendicularly (rather than parallelly) oriented branchial surface, inner and outer ciliary bands (rather than two parallel inner bands), and lacking (rather than possessing) transverse ciliary dorsal ridges on each segment (Blake and Kudenov, 1978). The branchial orientation and ciliary pattern of $R$. australiana are more similar to those of Malacoceros (Hourdez et al., 2006) and Aonides (Radashevsky, 2015). R. glycera has two posterior pairs of digitiform nuchal lobes (rather than lacking nuchal lobes in the R. glutaea complex) on caruncle, and bears quadridentate (rather than tridentate) hooded hooks (Blake and Kudenov, 1978). R. inflata was named after its inflated anterior body region and its neuropodial hooded hooks starting from chaetiger 37, far posterior than those in the other Rhynchpsio species (Table 3 ). Not described but showed in figures (Figs. 113, 114 in Foster, 1971), R. inflata seems to resemble $R$. australiana in that they both have ciliated branchiae on inner and outer margins. Another species, $R$. tuberculata, however, is similar in morphology to species of the $R$. glutaea complex, except that it has three small tubercles on the underside of its lateral-frontal horns. Further study for $R$. australiana, $R$. glycera, $R$. inflata, and $R$. tuberculata, might uncover their divergences in phylogeny with the remaining Rhynchospio species.

Water flow caused by ciliary action of nototrochs may help to transfer the oxygen dissolved in seawater into tubes of some genera of Spioninae (Simon, 1967). In Rhynchospio aff. asiatica, however, the water flow is stimulated by ciliary beating on the inner side of paired branchiae and nototrochs of each segment, which leads to directional movement of water along the dorsum of the worm. The water flow on the dorsum of $R$. aff. asiatica could be observed from directional movement of small particles suspended in the water tunnel, indicating that it may have a function of transporting the gametes from anterior and middle fertile segments to the posterior 
hatchery formed by elongated capillaries. Given the similarity in the arrangement of ciliary bands, it may be reasonable to infer that perhaps this water flow system exists in all Rhynchospio species (perhaps excluding $R$. inflata and $R$. australiana which have perpendicularly oriented branchial surfaces), which can be confirmed by observing live specimens in the future. This feature may cause adaptive changes, given that high fertilization efficiency might be desirable for these spionids that produce only a small amount of sperm and oocytes (Radashevsky, 2007a).

Our study has contributed to a better understanding of the phylogeny of Spionidae. The genera within Spionidae could be basically divided into two clades/ subfamilies, i.e., Spioninae and Nerininae (Fig.5). Five genera (i.e., Dispio, Malacoceros, Marenzelleria, Rhynchospio, and Scolelepis) previously grouped within Nerininae due to their similarities in reproductive characteristics, such as thick-enveloped oocytes, ect-aquasperm, and broadcast spawning (Blake and Arnofsky, 1999), form a single clade with the other genera belonging to Spioninae with relatively high support values $(\mathrm{BS}=91 ; \mathrm{BPP}=1)$ in this study. This phylogenetic result is supported by the morphological evidence that all the five genera have branchiae on most of the segments (referring to morphology Group B), similar to that of Spio and Microspio, which belong to Spioninae (Blake and Arnofsky, 1999). Similar close relationships between these genera (i.e., Marenzelleria, Rhynchospio, Malacoceros, Dispio, and Scolelepis) and those belonging to Spioninae were also showed in phylogenetic results of Abe and Sato-Okoshi (2021), while they were grouped within Nerininae according to morphological characteristics (i.e., number of eyes, pigmentation, and the position of gastrotrochs). In addition, our phylogenetic results agree with that of Abe and Sato-Okoshi (2021) by showing that the two spioniform genera (i.e., Trochochaeta and Poecilochaetus) are clustered within the clade of Spionidae. The two phylogenetic analyses thus provided molecular evidences to support the proposal by Blake and Arnofsky (1999) that Trochochaetidae and Poecilochaetidae should be included within a broadly defined Spionidae.

The phylogenetic results (Fig.5) support the suggestion proposed by Hannerz (1956) and Radashevsky (2007b) that the ancestor of spionids might have thick-envelope oocytes, and thin-envelope oocytes is a derived trait in Spioninae. Given that thin-enveloped oocytes and introsperms have widespread occurrence in other annelid families (Jamieson and Rouse, 1989; Blake and Arnofsky, 1999), they might have occurred more than once in the evolutionary history of annelids, and their evolution within Spioninae could be considered as adaptive changes to various brooding activities, such as having capsules/egg mass with brooding in tube or brooding on the dorsum of female. With three spioniform genera, i.e., Spiophanes, Trochochaeta, and Poecilochaetus, at the base of the phylogenetic tree, our results further indicate that the common spionid ancestor might have no branchiae, and various arrangement patterns of branchiae (Groups A, B, C) together with various brooding/egg protection modes might be derived characteristics. This conclusion differs from the scenario proposed by Radashevsky (2007b) that the first spionid might have branchiae on most segments, which might be due to the basal position of the genera such as Marenzelleria, Dispio, Scolelepis, and Malacoceros in his cladistic analysis. Overall, our phylogenetic analysis and mapping of reproductive characteristics to the phylogenetic tree revealed a potential evolutionary history of reproductive characteristics in spionids.

\section{Taxonomic key to Rhynchospio species (modified from Radashevsky et al., 2014)}

1 Anterior body swollen; hooks in neuropodia from chaetiger 37....... R. inflata (Bimini Islands, Bahamas)

- Anterior body slender, hooks in neuropodia from earlier than chaetiger 37

2 Notopodia from chaetiger 1 lacking capillaries, hooks in neuropodia from chaetiger 8

R. australiana (West Australia, Australia)

- Notopodia from chaetiger 1 with capillaries, hooks in neuropodia from later than chaetiger $8 \ldots . . . .3$

3 Caruncle with two posterior pairs of digitiform nuchal lobes, hooks in neuropodia from chaetiger 27 quadridentate

R. glycera (New South Wales, Australia)

- Caruncle posteriorly narrow, without lobes, hooks in neuropodia from chaetigers $9-18$, tridentate...........4

4 Ventral side of prostomial horns with 3 minute tubercles, medially constructed

R. tuberculata (Honshu, Japan)

- Ventral side of prostomial horns smooth and tapered, without tubercles ..................................... 5

5 Anterior branchiae large, broad, foliaceous ....... 6

- Anterior branchiae of moderate size, elongate ...... 7

6 Caruncle anteriorly elevated above prostomium; up to 18 pygidial cirri or lobes 
R. foliosa (Hokkaido, Japan)

- Caruncle not elevated above prostomium; up to 32 pygidial cirri $R$. cf. foliosa (Oregon, USA)

7 Mature worm hooks in neuropodia of chaetigers 11-14 unidentate; from chaetiger 15 onwards tridentate ...... R. nhatrangi (Nha Trang Bay, Vietnam)

- Mature worm hooks in neuropodia all tridentate

8 Worm length up to $5 \mathrm{~mm}$ for 60 chaetigers; hooks in neuropodia from chaetigers 11-12; sperm in chaetigers 11-14, oocytes from chaetiger 15; pygidial cirri up to 3 pairs

R. darwini (Northern Territory and Queensland, Australia)

- Worm length up to $20 \mathrm{~mm}$ for 80 chaetigers; hooks in neuropodia from chaetigers 10-23; sperm in chaetigers 11 to $21-22$, oocytes from chaetigers $22-$ 24; pygidial cirri up to 6 pairs

R. asiatica (Kurile Islands)

- Worm length up to $11 \mathrm{~mm}$ for 59 chaetigers; hooks in neuropodia from chaetigers 14-17; sperm in chaetigers 11-14, oocytes from chaetiger 16-17; pygidial cirri 2-3 pairs ............................ $R$. aff. asiatica (Yellow Sea, East China Sea and Sea of Japan)

- Worm length up to $20 \mathrm{~mm}$ for 80 chaetigers; hooks in neuropodia from chaetiger 18; sperm in chaetigers 11 to $15-17$, oocytes from chaetigers $17-$ 19; pygidial cirri 4 pairs

R. arenincola (Pacific North America)

- Worm length up to $24 \mathrm{~mm}$ for 90 chaetigers; hooks in neuropodia from chaetiger 18; sperm in chaetigers 12 (rarely 11) to chaetigers 16-17, oocytes from chaetiger 18; pygidial cirri 2 pairs .

........R. glutaea (Atlantic and Pacific South America)

- Worm length up to $13 \mathrm{~mm}$ for 68 chaetigers; hooks in neuropodia from chaetigers 15-18; pygidial cirri 3-5 pairs

R. mzansi (Western Cape, South Africa)

\section{DATA AVAILABILITY STATEMENT}

The datasets generated and/or analyzed during the current study are available from the corresponding author on reasonable request.

\section{ACKNOWLEDGMENT}

We thank Mengsheng ZHANG, Shaoyue LI, Shuhui WANG, Liangli TU, Fanqi ZHAO, Haixia ZHONG, Wenyao CUI, Xiangjun YANG, Chen CHEN, Congcong SHAO, Lin ZHU, and Ankang TENG from College of Marine Life Sciences, Ocean University of China for assistance with collecting
Rhynchospio specimens. We also thank Dr. Vasily I. RADASHEVSKY for helpful information during the course of our study.

\section{References}

Abe H, Kondoh T, Sato-Okoshi W. 2016. First report of the morphology and rDNA sequences of two Pseudopolydora species (Annelida: Spionidae) from Japan. Zoological Science, 33(6): 650-658, https://doi.org/10.2108/ zs160082.

Abe H, Sato-Okoshi W. 2021. Molecular identification and larval morphology of spionid polychaetes (Annelida, Spionidae) from northeastern Japan. ZooKeys, 1015: 1-86, https://doi.org/10.3897/zookeys.1015.54387.

Blake J A, Arnofsky P L. 1999. Reproduction and larval development of the spioniform Polychaeta with application to systematics and phylogeny. Hydrobiologia, 402: 57-106, https://doi.org/10.1023/A:1003784324125.

Blake J A, Kudenov J D. 1978. The Spionidae (Polychaeta) from southeastern Australia and adjacent areas with a revision of the genera. Memoirs of the National Museum of Victoria, 39: 171-280.

Blake J A, Maciolek N J, Meißner K. 2020. Sedentaria: sabellida/spionida. In: Purschke G, Böggemann $\mathrm{M}$, Westheide W eds. Handbook of Zoology. Annelida. Volume 2 Pleistoannelida, Sedentaria II. Berlin: De Gruyter. p.1-103.

Blake J A, Maciolek N J. 2019. 7.3.1.9. Longosomatidae hartman, 1944. In: Purschke G, Böggemann M, Westheide W eds. Handbook of Zoology. Annelida. Volume 1: Annelida Basal Groups and Pleistoannelida, Sedentaria I. Berlin: De Gruyter. p.457-465.

Blake J A, Petti M A V. 2019. 5.1 Apistobranchidae. In: Purschke G, Böggemann M, Westheide W eds. Handbook of Zoology. Annelida. Volume 1 Annelida Basal Groups and Pleistoannelida, Sedentaria I. Berlin: De Gruyter. p.133-134.

Bleidorn C, Vogt L, Bartolomaeus T. 2003. A contribution to sedentary polychaete phylogeny using $18 \mathrm{~S}$ rRNA sequence data. Journal of Zoological Systematics and Evolutionary Research, 41(3): 186-195, https://doi. org/10.1046/j.1439-0469.2003.00212.x.

Bleidorn C, Vogt L, Bartolomaeus T. 2005. Molecular phylogeny of lugworms (Annelida, Arenicolidae) inferred from three genes. Molecular Phylogenetics and Evolution, 34(3): 673679, https://doi.org/10.1016/j.ympev.2004.11.019.

Bonifácio P, Martinez-Arbizu P, Menot L. 2019. Alpha and beta diversity patterns of polychaete assemblages across the nodule province of the eastern Clarion-Clipperton Fracture Zone (equatorial Pacific). Biogeosciences, 17(4): 865-886, https://doi.org/10.5194/bg-17-865-2020.

Brown S, Rouse G, Hutchings P, Colgan D. 1999. Assessing the usefulness of histone $\mathrm{H} 3, \mathrm{U} 2 \mathrm{snRNA}$ and $28 \mathrm{~S}$ rDNA in analyses of polychaete relationships. Australian Journal of Zoology, 47(5): 499-516, https://doi.org/10.1071/ ZO99026. 
Chlebovitsch V V. 1959. Species of Polychaeta worms from the Kurile Islands, which are new or recorded for the first time in the USSR fauna. Zoologicheskii Zhurnal, 38(2): 167-181. (in Russian)

Colgan D J, McLauchlan A, Wilson G D F, Livingston S P, Edgecombe G D, Macaranas J, Cassis G, Gray M R. 1998. Histone H3 and U2 snRNA DNA sequences and arthropod molecular evolution. Australian Journal of Zoology, 46(5): 419-437, https://doi.org/10.1071/ZO98048.

Collier M, Jones M L. 1967. Observations on the reproductive and general morphology of Streblospio benedicti Webster. Biology Bulletin, 133: 462.

Darriba D, Taboada G L, Doallo R, Posada D. 2012. jModelTest 2: more models, new heuristics and parallel computing. Nature Methods, 9(8): 772, https://doi.org/10.1038/ nmeth.2109.

Delgado-Blas V H, Díaz-Díaz Ó. 2010. Description of two new species of Malacoceros and Rhynchospio spionids (Polychaeta: Spionidae) from the Grand Caribbean region. Revista Chilena de Historia Natural, 83(2): 249-257, https://doi.org/10.4067/S0716-078X2010000200006.

Dorsey J H. 1977. A new species of Rhynchospio (Polychaeta: Spionidae) from San Clemente Island, California. Bulletin of the Southern California Academy of Sciences, 76(1): $1-4$.

Du Y F, Xu K D, Lei Y L, Day R H. 2011. Annual quantitative distribution of meiofauna in relation to sediment environment in Qingdao Bay. Acta Ecologica Sinica, 31(2): 431-440. (in Chinese with English abstract)

Edgar R C. 2004. MUSCLE: multiple sequence alignment with high accuracy and high throughput. Nucleic Acids Research, 32(5): 1792-1797, https://doi.org/10.1093/nar/ gkh340.

Edler D, Klein J, Antonelli A, Silvestro D. 2021. raxmlGUI 2.0: A graphical interface and toolkit for phylogenetic analyses using RAxML. Methods in Ecology and Evolution, 12(2): 373-377, https://doi.org/10.1111/2041210X.13512.

Ehlers E. 1897. Polychaeten. Ergebnisse der Hamburger Magahlaensischen Sammelreise. Friederichsen \& Co, Hamburg. p.1-148.

Foster N M. 1971. Spionidae (Polychaeta) of the gulf of Mexico and the Caribbean sea. Studies on the Fauna of Curacao and other Caribbean Islands, 36(1): 1-183.

Giribet G, Carranza S, Baguñà J, Riutort M, Ribera C. 1996. First molecular evidence for the existence of a Tardigrada + Arthropoda clade. Molecular Biology and Evolution, 13(1): 76-84, https://doi.org/10.1093/oxfordjournals. molbev.a025573.

Grube A E. 1850. Die familien der anneliden. Archiv für Naturgeschichte, 16(1): 249-364.
Guggolz T, Meißner K, Schwentner M, Dahlgren T G, Wiklund H, Bonifácio P, Brandt A. 2020. High diversity and panoceanic distribution of deep-sea polychaetes: Prionospio and Aurospio (Annelida: Spionidae) in the Atlantic and Pacific Ocean. Organisms Diversity \& Evolution, 20(2): 171-187, https://doi.org/10.1007/s13127-020-00430-7.

Hall K A, Hutchings P A, Colgan D J. 2004. Further phylogenetic studies of the Polychaeta using 18S rDNA sequence data. Journal of the Marine Biological Association of the United Kingdom, 84(5): 949-960, https://doi.org/10.1017/S0025315404010240h.

Hannerz L. 1956. Larval development of the polychaete families Spionidae Sars, Disomidae Mesnil and Poecilochaetidae n. fam. in the Gullmar Fjord (Sweden). Zoologiska bidrag från Uppsala, 31: 1-204.

Hartman O. 1936. New species of Spionidae (Annelida Polychaeta) from the coast of California. University of California Publications in Zoölogy., 41(6): 45-52.

Hourdez S, Desbruyères D, Laubier L. 2006. Malacoceros samurai, a new species of Spionidae (Annelida: Polychaeta) from hydrothermal vent chimney walls on the south East Pacific Rise. Proceedings of the Biological Society of Washington, 119(4): 592-599, https://doi.org/10.2988/0006324X(2006)119[592:MSANSO]2.0.CO;2.

Imajima M. 1991. Spionidae (Annelida, Polychaeta) from Japan. VI. The genera Malacoceros and Rhynchospio. Bulletin of the National Science Museum, Series A (Zoology), Tokyo, 17(1): 5-17.

Institute of Oceanology, Chinese Academy of Sciences, Liu R Y. 2008. Checklist of Marine Biota of China Seas. Science Press, Beijing. 1267p.

Jamieson B G M, Rouse G W. 1989. The spermatozoa of the Polychaeta (Annelida): an ultrastructural review. Biological Reviews, 64(2): 93-157, https://doi.org/10. 1111/j.1469-185X.1989.tb00673.x.

Ji X X. 2012. The Ecological Study of Macrobenthos in Qingdao Bay Intertidal Zone. Ocean University of China, Qingdao. (in Chinese with English abstract)

Kimura M. 1980. A simple method for estimating evolutionary rates of base substitutions through comparative studies of nucleotide sequences. Journal of Molecular Evolution, 16(2): 111-120, https://doi.org/10.1007/BF01731581.

Knight-Jones E W. 1954. Relations between metachronism and the direction of ciliary beat in Metazoa. Journal of Cell Science, s3-95(32): 503-521.

Kumar S, Stecher G, Li M, Knyaz C, Tamura K. 2018. MEGA $\mathrm{X}$ : molecular evolutionary genetics analysis across computing platforms. Molecular Biology and Evolution, 35(6): 1547-1549, https://doi.org/10.1093/molbev/msy096.

Kupriyanova E K, Macdonald T A, Rouse G W. 2006. Phylogenetic relationships within Serpulidae (Sabellida, 
Annelida) inferred from molecular and morphological data. Zoologica Scripta, 35(5): 421-439, https://doi. org/10.1111/j.1463-6409.2006.00244.x.

Kupriyanova E K, Rouse G W. 2008. Yet another example of paraphyly in Annelida: molecular evidence that Sabellidae contains Serpulidae. Molecular Phylogenetics and Evolution, 46(3): 1174-1181, https://doi.org/10.1016/j. ympev.2007.10.025.

Lenaers G, Maroteaux L, Michot B, Herzog M. 1989. Dinoflagellates in evolution. A molecular phylogenetic analysis of large subunit ribosomal RNA. Journal of Molecular Evolution, 29(1): 40-51, https://doi. org/10.1007/BF02106180.

Mackie A S Y. 1996. Taxonomy and Phylogeny of spioniform Polychaetes (Annelida). University of Gothenburg, Gothenburg.

Meißner K, Bick A, Bastrop R. 2011. On the identity of Spio filicornis (O.F. Müller, 1776) - with the designation of a neotype, and the description of two new species from the North East Atlantic Ocean based on morphological and genetic studies. Zootaxa, 2815: 1-27.

Meißner K, Bick A, Guggolz T, Götting M. 2014. Spionidae (Polychaeta: Canalipalpata: Spionida) from seamounts in the NE Atlantic. Zootaxa, 3786(3): 201-245, https://doi. org/10.11646/zootaxa.3786.3.1.

Meißner K, Götting M. 2015. Spionidae (Annelida: 'Polychaeta': Canalipalpata) from lizard island, great barrier reef, Australia: the genera Malacoceros, Scolelepis, Spio, Microspio, and Spiophanes. Zootaxa, 4019(1): 378413, https://doi.org/10.11646/zootaxa.4019.1.15.

Mincks S L, Dyal P L, Paterson G L J, Smith C R, Glover A G. 2009. A new species of Aurospio (Polychaeta, Spionidae) from the Antarctic shelf, with analysis of its ecology, reproductive biology and evolutionary history. Marine Ecology, 30(2): 181-197, https://doi.org/10.1111/j. 14390485.2008.00265.x.

Palumbi S R, Martin A, Romano S, McMillan W O, Stice L, Grabowski G. 1991. The Simple Fool's Guide to PCR. Version 2.0. University of Hawaii, Honolulu. p.1-45.

Radashevsky V I, Malyar V V, Pankova V V, Nuzhdin S V. 2016a. Molecular analysis of six Rhynchospio Hartman, 1936 species (Annelida: Spionidae) with comments on the evolution of brooding within the group. Zootaxa, 4127(3): 579-590, https://doi.org/10.11646/zootaxa.4127.3.10.

Radashevsky V I, Neretina T V, Pankova V V, Tzetlin A B, Choi J W. 2014. Molecular identity, morphology and taxonomy of the Rhynchospio glutaea complex with a key to Rhynchospio species (Annelida, Spionidae). Systematics and Biodiversity, 12(4): 424-433, https://doi. org/10.1080/14772000.2014.941039.

Radashevsky V I, Pankova V V, Malyar V V, Neretina T V,
Choi J W, Yum S, Houbin C. 2020. Molecular analysis of Spiophanes bombyx complex (Annelida: Spionidae) with description of a new species. PLoS One, 15(7): e234238, https://doi.org/10.1371/journal.pone.0234238.

Radashevsky V I, Pankova V V, Neretina T V, Stupnikova A N, Tzetlin A B. 2016b. Molecular analysis of the Pygospio elegans group of species (Annelida: Spionidae). Zootaxa, 4083(2): 239-250, https://doi. org/10.11646/zootaxa.4083.2.4.

Radashevsky V I, Pankova V V. 2013. Shell-boring versus tube-dwelling: is the mode of life fixed or flexible? Two cases in spionid polychaetes (Annelida, Spionidae). Marine Biology, 160(7): 1619-1624, https://doi. org/10.1007/S00227-013-2214-8.

Radashevsky V I, Yurchenko O V, Alexandrova Y N. 2018. Fine structure of the gametes and spermiogenesis in Spiophanes uschakowi (Annelida: Spionidae) from the Sea of Japan, with comments on fertilization biology in broadcast-spawning spionids. Micron, 115: 32-40, https:// doi.org/10.1016/j.micron.2018.08.005.

Radashevsky V I. 2007a. Morphology and biology of a new Rhynchospio species (Annelida: Spionidae) from the South China Sea, Vietnam, with the review of Rhynchospio taxa. Journal of Natural History, 41(17-20): 985-997, https://doi.org/10.1080/00222930701376717.

Radashevsky V I. 2007b. Evolution of reproduction in Spionidae (Annelida). In: Proceedings of the 9th International Polychaete Conference. Portland, Maine.

Radashevsky V I. 2015. Spionidae (Annelida) from lizard island, great barrier reef, Australia: the genera Aonides, Dipolydora, Polydorella, Prionospio, Pseudopolydora, Rhynchospio, and Tripolydora. Zootaxa, 4019: 635-694, https://doi.org/10.11646/zootaxa.4019.1.22.

Rambaut A, Drummond A J, Xie D, Baele G, Suchard M A. 2018. Posterior summarization in Bayesian phylogenetics using tracer 1.7. Systematic Biology, 67(5): 901-904, https://doi.org/10.1093/sysbio/syy032.

Read G, Fauchald K. 2021. World polychaeta database. spionidae grube, 1850. http://www.marinespecies.org/ aphia.php? $\mathrm{p}=$ taxdetails\&id=913. Accessed on 2021-0410.

Rengaiyan P, Ingole B. 2018. 18S rDNA sequencing data of benthic polychaetes from the Eastern Arabian Sea. Data in Brief, 20: 1749-1752, https://doi.org/10.1016/j. dib.2018.09.015.

Ronquist F, Huelsenbeck J P. 2003. MrBayes 3: bayesian phylogenetic inference under mixed models. Bioinformatics, 19(12): 1572-1574, https://doi.org/10. 1093/bioinformatics/btg180.

Rousset V, Pleijel F, Rouse G W, Erséus C, Siddall M E. 2007. A molecular phylogeny of annelids. Cladistics, 23(1): 41- 
63, https://doi.org/10.1111/j.1096-0031.2006.00128.x.

Sato-Okoshi W, Abe H, Nishitani G, Simon C A. 2017. And then there was one: Polydora uncinata and Polydora hoplura (Annelida: Spionidae), the problematic polydorid pest species represent a single species. Journal of the Marine Biological Association of the United Kingdom, 97(8): 1675-1684, https://doi.org/10.1017/S002531541600093X.

Sato-Okoshi W, Okoshi K, Abe H, Li J Y. 2013. Polydorid species (Polychaeta, Spionidae) associated with commercially important mollusk shells from eastern China. Aquaculture, 406-407: 153-159, https://doi. org/10.1016/j.aquaculture.2013.05.017.

Sigvaldadóttir E, Mackie A S Y, Pleijel F. 1997. Generic interrelationships within the Spionidae (Annelida: Polychaeta). Zoological Journal of the Linnean Society, 119(4): 473-500, https://doi.org/10.1111/j.1096-3642.1997. tb00144.x.

Simon C A, Sato-Okoshi W, Abe H. 2019a. Hidden diversity within the cosmopolitan species Pseudopolydora antennata (Claparède, 1869) (Spionidae: Annelida). Marine Biodiversity, 49(1): 25-42, https://doi.org/10. 1007/s12526-017-0751-y.

Simon C A, Williams L G, Henninger T. 2019b. A new species of Rhynchospio (Annelida: Spionidae) in South Africa. Marine Biodiversity, 49(2): 663-672, https://doi. org/10.1007/s12526-017-0842-9.

Simon J L. 1967. Reproduction and larval development of Spio setosa (Spionidae; Polychaeta). Bulletin of Marine Science, 17(2): 398-431.

Söderström A. 1920. Studien über die Polychätenfamilie Spionidae. Almquist and Wicksells, Uppsala. 286p.

Struck T H, Nesnidal M P, Purschke G, Halanych K M. 2008. Detecting possibly saturated positions in $18 \mathrm{~S}$ and $28 \mathrm{~S}$ sequences and their influence on phylogenetic reconstruction of Annelida (Lophotrochozoa). Molecular Phylogenetics and Evolution, 48(2): 628-645, https://doi. org/10.1016/j.ympev.2008.05.015.

Struck T H, Purschke G. 2005. The sister group relationship of Aeolosomatidae and Potamodrilidae (Annelida: "Polychaeta") — a molecular phylogenetic approach based on 18S rDNA and cytochrome oxidase I. Zoologischer Anzeiger - A Journal of Comparative Zoology, 243(4): 281293, https://doi.org/10.1016/j.jcz.2005.01.001.

Struck T H, Schult N, Kusen T, Hickman E, Bleidorn C, McHugh D, Halanych K M. 2007. Annelid phylogeny and the status of Sipuncula and Echiura. BMC Evolutionary Biology, 7(1): 57, https://doi.org/10.1186/1471-2148-7-57.

Vaidya G, Lohman D J, Meier R. 2011. SequenceMatrix: concatenation software for the fast assembly of multigene datasets with character set and codon information. Cladistics, 27(2): 171-180, https://doi.org/10.1111/j.1096- 0031.2010.00329.x.

Van der Auwera G, Chapelle S, De Wächter R. 1994. Structure of the large ribosomal subunit RNA of Phytophthora megasperma, and phylogeny of the oomycetes. FEBS Letters, 338(2): 133-136, https://doi.org/10.1016/00145793(94)80350-1.

Vortsepneva E, Tzetlin A, Purschke G, Mugue N, Haß-Cordes E, Zhadan A. 2008. The parasitic polychaete known as Asetocalamyzas laonicola (Calamyzidae) is in fact the dwarf male of the spionid Scolelepis laonicola (comb. nov.). Invertebrate Biology, 127(4): 403-416, https://doi. org/10.1111/j.1744-7410.2008.00137.x.

Wang Z. 2015. The Ecological and Morphological Study of Macrobenthos in the Intertidal Zone of Qingdao Cove. Ocean University of China, Qingdao. (in Chinese with English abstract)

Williams L G, Karl S A, Rice S, Simon C. 2017. Molecular identification of polydorid polychaetes (Annelida: Spionidae): is there a quick way to identify pest and alien species? African Zoology, 52(2): 105-117, https://doi.org/ 10.1080/15627020.2017.1313131.

Wu B L, Lu H, Qiu JW. 1993. The macrobenthos of the sewage discharging area of Qingdao cove - a cladistic analysis. Acta Scientiae Circumstantiae, 13(1): 121-126. (in Chinese with English abstract)

Ye L T, Cao C, Tang B, Yao T, Wang R X, Wang J Y. 2017. Morphological and molecular characterization of Polydora websteri (Annelida: Spionidae), with remarks on relationship of adult worms and larvae using mitochondrial COI gene as a molecular marker. Pakistan Journal of Zoology, 49(2): 699-710, https://doi. org/10.17582/journal.pjz/2017.49.2.699.710.

Ye L T, Tang B, Wu K C, Su Y L, Wang R X, Yu Z N, Wang J Y. 2015. Mudworm Polydora lingshuiensis sp. $\mathrm{n}$ is a new species that inhabits both shell burrows and mudtubes. Zootaxa, 3986(1): 88-100, https://doi.org/10.11646/ zootaxa.3986.1.4.

Ye L T, Wu L, Wang J Y, Li Q Z, Guan J L, Luo B. 2019a. First report of black-heart disease in Kumamoto oyster Crassostrea sikamea spat caused by Polydora lingshuiensis in China. Diseases of Aquatic Organisms, 133(3): 247-252, https://doi.org/10.3354/dao03352.

Ye L T, Yao T, Wu L, Lu J, Wang J Y. 2019b. Morphological and molecular diagnoses of Polydora brevipalpa Zachs, 1933 (Annelida: Spionidae) from the shellfish along the coast of China. Journal of Oceanology and Limnology, 37(2): 713-723, https://doi.org/10.1007/s00343-0197381-0.

Zhang Y J, Chen C, Qiu J W. 2018. Sexually dimorphic scale worms (Annelida: Polynoidae) from hydrothermal vents in the Okinawa Trough: two new species and two new sex 
morphs. Frontiers in Marine Science, 5: 112, https://oi. org/10.3389/fmars.2018.00112.

Zhou H, Zhang Z N, Chen H Y, Sun R H, Wang H, Guo L, Pan H J. 2010a. Integrating a DNA barcoding project with an ecological survey: a case study on temperate intertidal polychaete communities in Qingdao, China. Chinese Journal of Oceanology and Limnology, 28(4): 899-910, https://doi.org/10.1007/s00343-010-9131-1.

Zhou J, Ji W W, Li X Z. 2010b. Records of Polydora complex spionids (Polychaeta: Spionidae) from China's coastal waters, with emphasis on parasitic species and the description of a new species. Marine Fisheries, 32(1): $1-15$.
Zhou J, Li X Z. 2009. Report of Prionospio complex (Annelida: Polychaeta: Spionidae) from China's waters, with description of a new species. Acta Oceanologica Sinica, 28(1): 116-127.

Zhou J. 2008. Study on the Taxonomy and Faunistic Characters of Families Paraonidae and Spionidae (Annelida: Polychaeta) from China Seas. Graduate University of Chinese Academy of Sciences, Beijing. (in Chinese with English abstract)

Zrzavý J, Říha P, Piálek L, Janouškovec J. 2009. Phylogeny of Annelida (Lophotrochozoa): total-evidence analysis of morphology and six genes. BMC Evolutionary Biology, 9(1): 189, https://doi.org/10.1186/1471-2148-9-189.

\section{Electronic supplementary material}

Supplementary material (Supplementary Table S1, Supplementary Fig.S1, and Supplementary videos S1-S4) is available in the online version of this article at https://doi.org/10.1007/s00343-021-1068-z. 